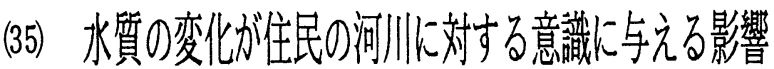

How People's Opinion on A River Changes According to The Change of Its Water Quality

$$
\begin{gathered}
\text { 小浜 明* 江成 敬次郎 } \\
\text { Akira KOHAMA }{ }^{*} \text {, Kei jiro ENARI }
\end{gathered}
$$

ABSTRACT; This paper is designed to present the correlaton between water quality of a river and people's opinion about it.

Umeda River, which is running through the central area of Sendai, has improved its water quality in recent 25 years, particularly in the middle reaches.

Opinion of people who live along the midstream of the river was examined and analyzed comparing with opinion of those who live in different areas, along the upper and lowerstream.

The result indicates that:

1. People who are along the midstream feels that the river became clearer and that they need to keep it clear. They feel that more strongly than people in other areas do.

Particularly people over 30 have recognized the improved clearness of the river.

And, since local river clearing activities are conducted by rather aged people,

- the survey showed they' re over 45 , these clearing will soon be discontinued, if there isn' $t$ any administrative guidance.

2. Only a subtle change in BOD didn't cause noticeable change in people's opinion. They even grow the negative impression on its clearness when the change is not remarkable enough.

KEYWORDS; Water Quality, People's Opinion, Organic Pollution, River-Clearning

1.はじめに

河川の污濁状況は、かつての深刻な状態からは脱してきている。しかし、現在も都市内中小河川の污濁レ ベルは依然として高い状態にある。しかも、污濁の状況は市内中心部から周辺部へ移りつつある。

今回報告する梅田川の污濁の歴史もこの例外でなく、ここ2 5 年余りの污濁状況を B O D值の変化によっ て流域別に概観すると、上流域での「微減」と、中流域での「激減後微減」、下流域でも「微減後微増」が 傾向として見られる。（表－1） ${ }^{11}$ からわかるように、現在流域中もっとも水質がよい流域は中流域という ことになっている。

さて、このような污濁状況の変化はこの川の流域に住む人々にどのような影響を与えたのだろうか。特に B O D 值の劇的な変化を呈した中流域では、住民の川に対する意識にどのような変化をもたらしたのだろう か。

本報は、水質の変化が人々の川に対する意識にどのような変化を生じさせるのかを、BOD值の劇的変化 を体験した中流域住民の梅田川に対する関心、意識、過去の体験、清掃活動状況を中心に、上・下流域住民 と比較しながら、アンケート調査により明らかにすることを目的としている。

* 東北工業大学 TOUHOKU INSTITUTE OF TECHNOLOGY, Sendai, Japan 
2. 梅田川の概要と調査地域の選定

梅田川は仙台市青葉区国見ケ丘 $3 丁$ 目 付近から東に流れ、あけぼの町、台原、 中江、平成、扇町などを流下して福田町 で七北田川に合流している。この川の全 長は約 $14 \mathrm{~km}$ 、流域面積約 $40 \mathrm{~km}$ 、雨水 (表-1）年代後半每のBODO)変化 (4年間0平均)（梅田川:D類型，8mg/l）

\begin{tabular}{|c|c|c|c|}
\hline & 1967〜 70年 & 1977 80年 & 1987 90作 \\
\hline 上流（本沢橋付近） & 6.11 & 5.39 & 2.20 \\
\hline 中流（太洞見橋付近） & 26.11 & 2.28 & 1.75 \\
\hline 下流（福门桴付近） & 9.70 & 4.28 & 6.85 \\
\hline
\end{tabular}

調節池（うどう溜池）を起点とする典型的な都市型河川である。

各流域の特徴は、最近の調査によると、

(1)上流域では河川の自浄作 用も㗢いているが、それを上 回る生活排水の流入によって 水質が悪化している。

(2)中流域では、広瀬川上流 の四ツ谷堰から取水された河 川水が流入することによる希 釈効果と河川の自浄作用によ る污濁物の減少によって、か なりの水質改善がみられる。

(3)下流域では、主に流域事

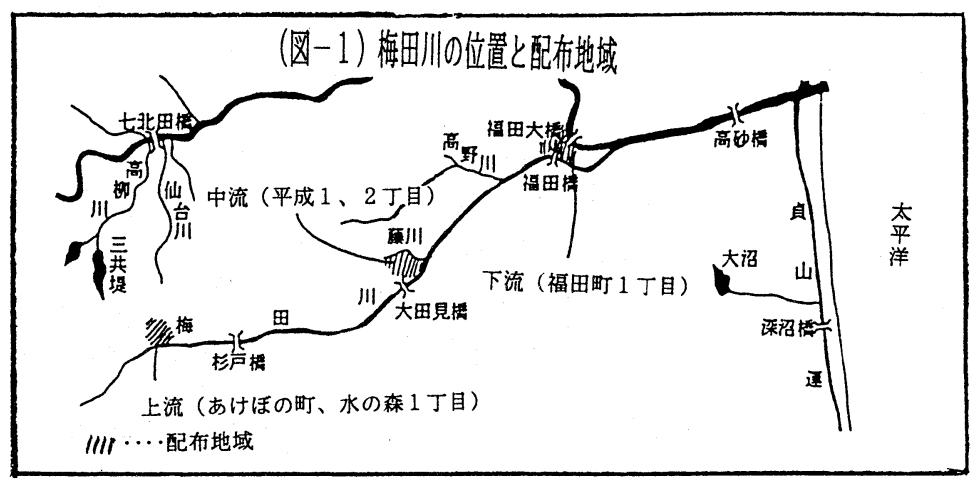

業所や住宅からの排水によって、中流域で改善された水質が悪化しており、自浄能力は流域中もっとも小さ い。と、特徴づけられている2)。

上記の地域を考慮し、調查地点には、住民が 仙台市中心部に入る場合梅田川を通る地域を地 図上から選んだ。その結果、上流域にはあけぼ の町・水の森 1 丁目、中流域には平成 $1 \cdot 2 丁$ 目、下流域には福田町 1 丁目と 2 丁目の一部を 決定した（図一 1 ）。

これらの地域は、上流域が新興住宅地・山の

\begin{tabular}{|c|c|c|c|c|c|}
\hline & \multicolumn{3}{|c|}{ (表-2) 質問票の回收絬果 } & \multicolumn{2}{|c|}{ 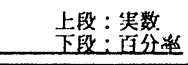 } \\
\hline & 配们数 & 可收(1) & 国收(2) & 䟭这 & 流域别小計 \\
\hline 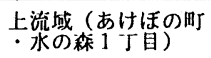 & 197 & $\begin{array}{r}64 \\
32.5\end{array}$ & $\begin{array}{c}5.6 \\
28.4\end{array}$ & $\begin{array}{r}4 \\
2.0\end{array}$ & $\begin{array}{r}124 \\
62.9\end{array}$ \\
\hline $\begin{array}{l}\text { 中流域（絔成 } 1 \cdot 2 \\
\text { 丁目） }\end{array}$ & 181 & $\begin{array}{l}66 \\
36.5\end{array}$ & $\begin{array}{c}52 \\
28.7\end{array}$ & $\begin{array}{c}3 \\
1.7\end{array}$ & $\begin{array}{r}121 \\
66.9\end{array}$ \\
\hline $\begin{array}{l}\text { 下流域（福回町 } 1 \text {. } \\
2 \text { 丁 }\end{array}$ & 222 & $\begin{array}{c}56 \\
25.2\end{array}$ & $\begin{array}{l}68 \\
30.7\end{array}$ & $\begin{array}{c}2 \\
0.9\end{array}$ & $\begin{array}{r}126 \\
56.8\end{array}$ \\
\hline 項目别合計 & 600 & $\begin{array}{r}186 \\
31.0 \\
\end{array}$ & $\begin{array}{r}176 \\
29.3 \\
\end{array}$ & $\begin{array}{l}11 \% \\
1.8\end{array}$ & $\begin{array}{r}373 \\
62.2 \\
\end{array}$ \\
\hline
\end{tabular}

手、中流域が旧市街地、下流域が農業・工業地区（一部商業地区）にあたる ${ }^{3)}$ 。

\section{3. 調查方法}

調査は、対象地域の川の流れに対して直角方向に $500 \mathrm{~m}$ の地点までの各家々にアンケート用紙を配 布し、数日後に回収した。回収しきれなかった分は 催促状を入れ、再度回収をした。

回収結果は（表一2）の通りである。全回収率は 62 . 2\%。回収率の差も川に対する意識の差と考 えると、中流域の住民は下流域の住民に比べ、川へ の関心が高いことが予想された（ $\chi^{2}$ 検定 : 中キ下 : $\mathrm{p}<0.05) 。$

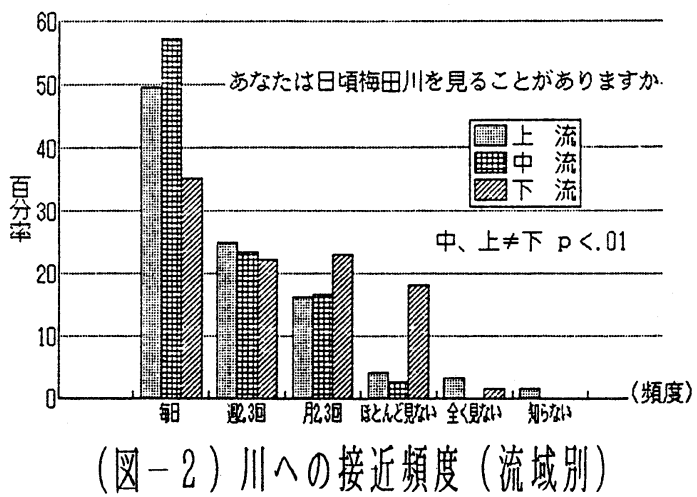

4. 結果と考察 
4. 1 属性

回答者は各流域とも 60 歳以上が全体の半数 近くをしめている。また、上流域は女性の、中 -下流域は男性の回答者が多いく $\chi^{2}$ 検定 : 上 $\neq$ 中 : $p\langle 0.05\rangle$ 。この男女差が職業にも影響し、 上流域ほど主婦、無職層が多く、流域が下がる につれて農業層、自営層が多くなる。このこと は調査地点の概要ともほぼ一致する。

さらに、居住年数にはそれほど差はなく、下 流域でのバラッキが目立つ。〈上:平夠20.1年(SD10.1) 、中:26.5(13.3)、下:21.2(20.7)〉。アパート、マ ンションの層が下流域に多く見られ、それが居 住年数のバラツキにあらわれたと思われる。な お下水道は、上・中流域ではすでに施設されて いるものの、下流域では一部のみである。その ため、汲み取り率は上流域約 $8 \%$ 、中流域約 2 \%、下流域約 $60 \%$ であった。

\section{2 日常生活の中の川とのかかわり}

（1）梅田川を「（毎日）見ている」と回答 した人の割合が上・中流域の住民に高い（図-2）

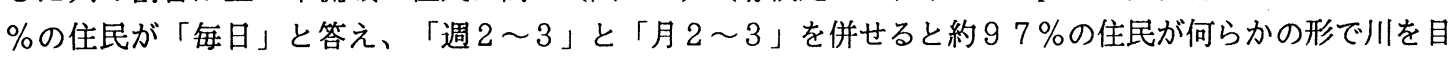
にしていることになる。また、中流域の住民は川を「まったく見ない」「知らない」人はいない。この流域 は他の流域に比べ、日常生活の中で梅田川へ接近する機会が多いといえる。

（2）ここ一年川の水に入って遊ぶ子どもの姿を「（よく+ときどき）見た」と答えた人は、上流域約 2

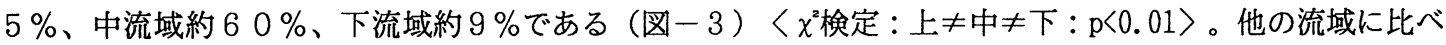
中流域では、川に接近する機会の多さが子どもの入水するのを見る機会を増やしている。と同時に「川への アプローチの有無」や「水深」、「学校の禁止指導」などによる影響も考慮する必要があるが、子どもが水 に入れる状態にあることは確かである。

（３）ここ一年梅田川の水を「（いつも十ときど き）臭いと感じている」と答えた人の割合は、上流 域約 $20 \%$ 、中流域約 $25 \%$ 、下流域約 $40 \%$ 、

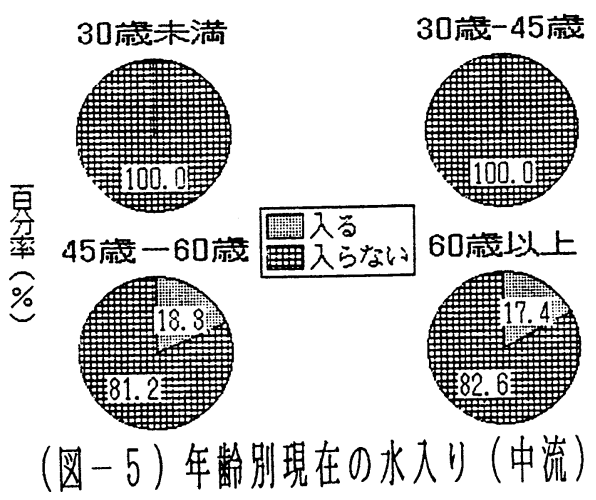

現在川のによいが「するっと「しない」と回答した人の比蒜

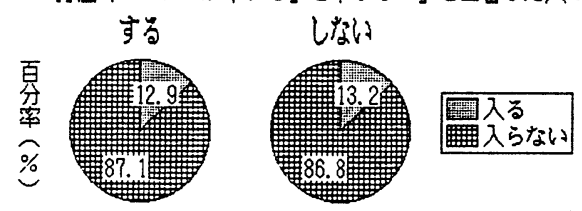

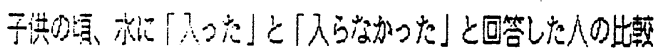

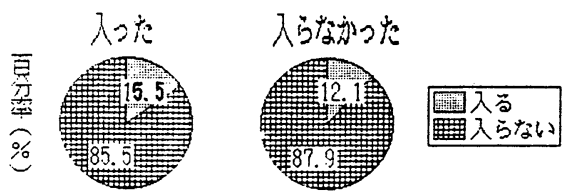

（图一－6）見在の水入体娩と川のにおい ・子どもの頃の水入りの関係（中流） 
流域が下がるにつれ「臭い」と感じている人の割合が高い （図一-4）。中流域は現在、全流域中最も B O D 值が低い にもかかわらず、「莫い」と感じている人の割合がそれほ ど低くない。

アンケートの自由記述欄に「雨の日がくさい（男・70 歳以上）」「雨の日にトイレットペーパー等も流れる（男 • $50 \sim 54$ 歳）」など、合流式の問題点が挙げられてお り、このことが現在「川の水を臭い」と感じている人の割 合を下げられない原因と考えられる。

（4）ここ一年梅田川の水に「（よく+ときどき）入っ た」と答えた人が中流域のみで約 $10 \%$ みられた。「入つ た」と答えた全ての人が「45歳以上」である（図一 5 ）。 これらの人の間には、「子どもの頃の水入り体験の有無」 や「現在川が臭い」（㘡一6）といったことに影響されて いない。

自由記述欄に「清掃活動や水辺のフェスティバル（イベ ント）が行なわれている（女・30〜34歳）」とあると ころから、おそらくこれらの活動の中心となっている層が

$\ulcorner 45$ 歳以上」と推測される。

\section{3 子どもの頃との比較}

（1）子どもの頃梅田川流域に「住んでいた人」の割合 は、上流域約 $15 \%$ 、中流域約 $35 \%$ 、下流域約 $40 \%$ と 流域が下がるにつれてその割合は多くなる。

（2）子どもの頃梅田川の水を「（いつも十ときど き）臭いと感じたことがある」と回答した人の割合は、 上流域約 $25 \%$ 、中流域約 $50 \%$ 、下流域約 $25 \%$ で ある。中流域で臭いと感じた割合は「30歳以上」に 多く、この傾向は年令が上がるにつれて高くなる（図 $-7)$ 。

（3）子どもの頃梅田川に「（よく+ときどき）入 つた」と回答した人の割合は、上流域約 $15 \%$ 、中流 域約 $40 \%$ 、下流域約 $30 \%$ である。中流域で入った と回答した割合が「30 歳未満」で高い（図-8）。

(4) 子どもの頃より、梅田川の水質が「（とても+少 し）よくなってきてる」割合から「（とても+少し）悪く なってきている」の割合を引くと、上流域で約一8ポイン 卜、中流域で約 +25 ポイント、下流域で約-20ポイン トとなった（図－9）。この結果を（表－1）と比較して みると、BOD值が微減した上流域では少し悪く、激減し た中流域ではよく、近年微増した下流域では悪い評価を住 民が下していることがわかる。また、中流域でよい評価を 下している人の多くが「30 歳以上」であった（図-10）。

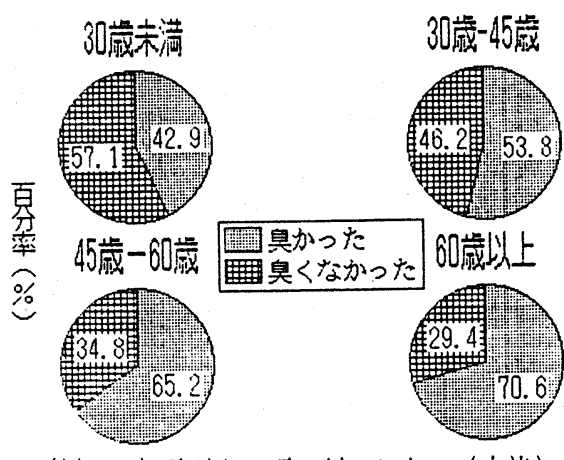

(困一7) 子どもの頃の川のにおい（中流）

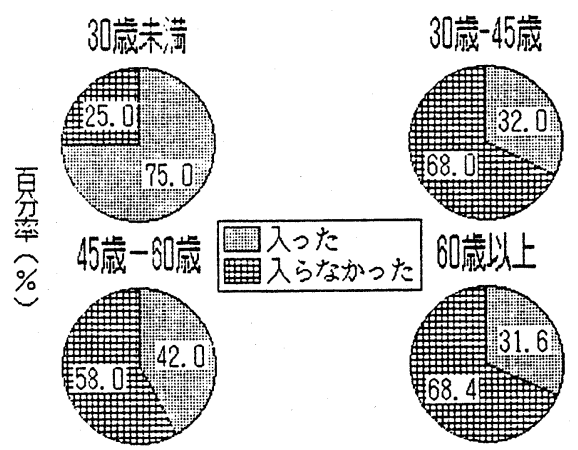

(图-8）年歯別子どもの頃の水入り（中流）

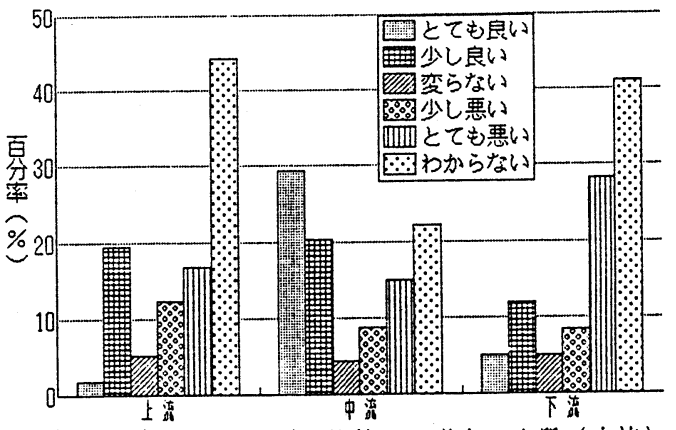

(图-9）子どもの頃と比較した現在の水質（中流）

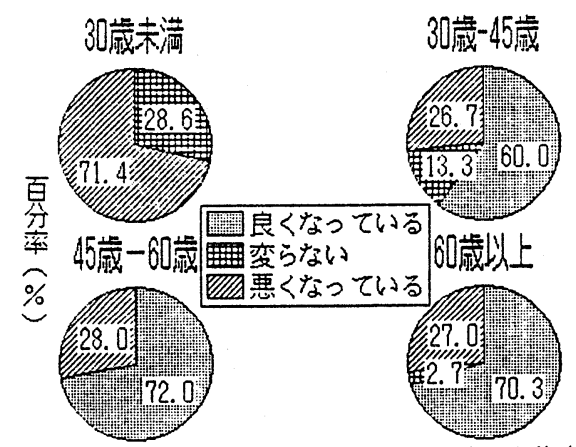

（因一10）年檄別子どもの頃と比较した現在の水質（中流） 
4. 4 清掃活動について

（1）町内会などで梅田川の清掃活動は「必要」と回答した 割合は、上流域約 $85 \%$ 、中流域約 $99 \%$ 、下流域約 $90 \%$ で ある。

（2）しかし、清掃活動が「行なわれている」と回答した割 茶 合は、上流域約 $10 \%$ 、中流域約 $80 \%$ 、下流域約 $50 \%$ とな \% り、清掃活動実施認知率は、中流域で特に高く、下 順に低くなる。しかし、中流域で清掃活動が「行なわれている」 と回答した多くは「30歳以上」の層であった（図一11）。こ のことは「水質がよくなってきている」と回答した層と一致する。

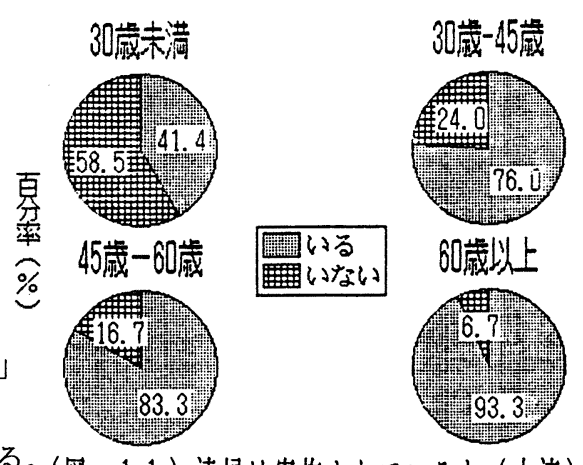

（3）さて、そのような清掃活動も「市と地域 住民のどちらが責任を持つべきか」と問うと、「 市」と回答した割合が、上流域約 $60 \%$ 、中流域 約 $45 \%$ 、下流域約 $60 \%$ という結果になった。 なお、前問（2）で清掃活動が「行なわれていな 岔 い・知らない」と回答した約 $20 \%$ 「清掃活動 \% は地域住民が責任を持つべき」と回答した人が、 中流域のみに見られた（図-12）。

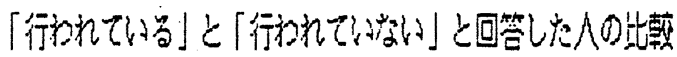

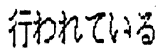

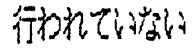

中流域住民は清掃活動への自治意識か高 $(\mathrm{mg} / \mathrm{l})$ い反面、参加者が高秢化しつつあり、住民 の約半数の人が行政が手を貸してほしいと 願っている。さらに清掃活動は「地域住民 がやることだ」と言っている中に、清掃活 動が行なわれていることさえ知らない人た ちが多くいる。清掃活動は地域住民がやる ことだが我々は清掃が行なわれていること を知らないという「無関心層」がこの流域 だけに存在している。

中流域の清掃活動は中心メンバーの「高 年齢化」と参加者の「二極分化」の波にさ らされていると予想される。
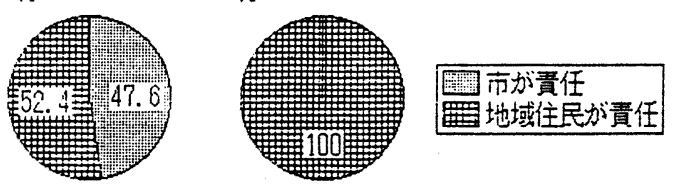

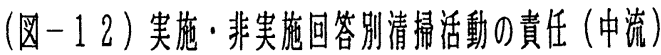

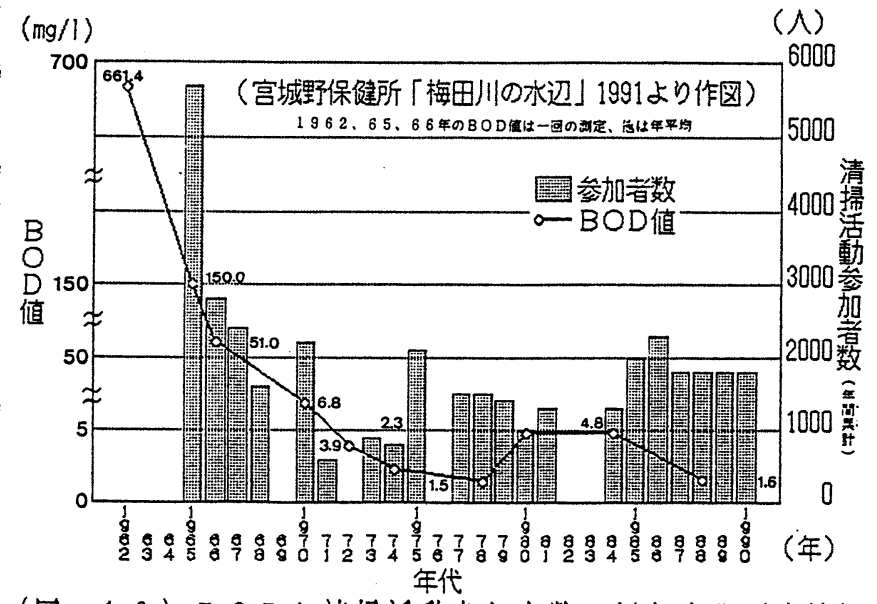

（4）ところで、中流域の清掃活動に関（図－１３）ＢＯDと清擩活動参加者数の経年変化（中流） する参加意識の高さは、梅田川の污濁の歴史と関係がありそうである。この流域の B O D值と清掃活動参加 者数の経年変化を示したのが（図ー13）であるが、清掃活動開始当時高かった B O D值が減少するに連れ、 参加者数が減つていく傾向がつかめる。「川の污れ」が清掃活動への「参加者数」に影響を与えるという関 係が見える。

4. 5 梅田川の暗渠化について

最後に梅田川の存在価值（目に見え、そこに水が流れている）を暗渠化を尋わることで探ってみたい。

（1）交通解消のためなら、梅田川に「フタをしてもかまわない」と回答した人の割合は、上流域約 45 \%、中流域約 $30 \%$ 、下流域約 $30 \%$ である。中流域では子どもの頃川に「入った」と回答した人ほど、ま た「現在（大変十少し）臭い」と回答した人ほど暗渠化に「反対」と回答した人の割合が高い（図一14）。 「現在臭い」と答えた人の多くは川岸の近くに住んでおり、その人たちに暗渠化に「反対」と回答した人の 
割合が高い（図-15）〈「臭い」と回答した人で「暗渠 に反対」と答えた人の川から自宅までの平均距離 : 約 1 $60 \mathrm{~m}$ 、「臭い」ので「暗渠に賛成」: 約 $260 \mathrm{~m}$ 。

\section{5.まとめ}

梅田川上、中、下流域住民に対するアンケート結果を 比較し、中流域に特徵的だったことについて述べ、その ことが水質の污濁状況とどのようにかかわっているかに ついてまとめてみたい。

中流域は他の流域に比べ、現在の「川への接近頻度」 「子どもの水遊び」「大人の水入り体験」「清掃活動実 施」に肯定的に回答した割合が高く、しかも「子どもの 時は臭」かったが、現在は「水質がよくなってきている」 と感じている人が多い。また「におい」に関しては、BOD值ほどの評価をしておらず、「臭い」要因の一 つに降雨時の下水の流れ込みが関係していることもわかった。しかし現在「莫い」という人たちに「暗渠化 には反対」という人が多く、多少莫い川でも存在していることに意義を認めている。

さて、年龄の側面から梅田川に対する意識をみると、

「 30 歳未満」の多くがB O D值が改善してきて いるにもかかわらず、現在の川は「污れてきてい る」と認識している。「30歳未満」は子ど も時代の梅田川をそれほど「污れた、臭い」 川と認識していなかった。そのため水に 入った人も多い。70 年代後半の水質が 改善された頃、子ども時代を過ごした 層である。

また、「45歳以上」が「現在水に 入った」り、清掃活動の中心となって いる。他の年齢層に見受けられない現 在の水入りは、 60 年代後半の水質が

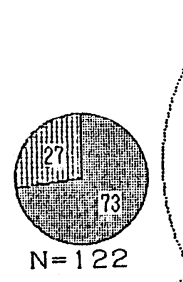

下流域

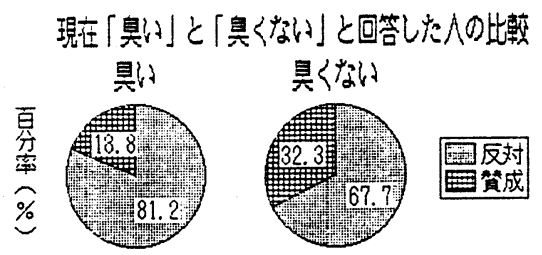

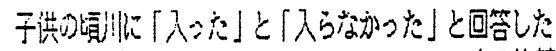
$\lambda \circ \hbar$

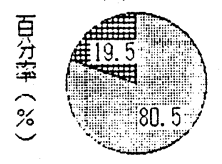

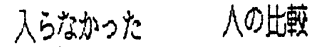

(因一-14）暗渠の賛否と川のにおい ・子どもの頃の水入りの関係（中流） 覀かった時を体験していることが活動の源泉になっていると考えられる。このことは清掃活動参加者の「高 年齢化」と、清掃活動に対する無関心層の存在による「二極分化」の危機を招いており、住民の半数が清掃 活動に行政の手助けが必要と少なからず思っている。

最後にこの調査を通して、住民の水質評価は非常にきびしいということが判明した。BOD值が少し改善 されただけでは、住民の水質評価に影響を与えることができない。恐らく劇的な改善が見られなければむし ろマイナスの評価を下すものと考えられる。

6.おわりに

この調査を実施にあたって協力頂いた、昨年研修生一丸敏彦、大畑和衛両氏に謝意を表したい。

\section{1 ）『仙台市衛生試験所報告書』より拔粋}

2 ）江成敬次郎他「梅田川の水質調査」『東北工業大学紀要』 1989.3

3 ）宮城野保健所『梅田川の水辺』1991.3 